\title{
Intracranial meningiomas in individuals under the age of 30; Analysis of risk factors, histopathology, and recurrence rate
}

\author{
Vikram C. Prabhu ${ }^{1 *}$, Edward C. Perry ${ }^{2}$, Edward Melian ${ }^{3}$, Kevin Barton ${ }^{4}$, Rong Guo ${ }^{5}$ and Douglas E. Anderson ${ }^{6}$ \\ *Correspondence: vprabhu@lumc.edu \\ 'Department of Neurological Surgery and Radiation Oncology Loyola University Medical Center, Maywood, IL, USA. \\ 2 Fellow in Neurological Surgery Vanderbilt University Medical Center, Nashville, TN. \\ ${ }^{3}$ Department of Radiation Oncology Loyola University Medical Center, Maywood, IL, USA. \\ ${ }^{4}$ Department of Internal Medicine Loyola University Medical Center, Maywood, IL, USA. \\ ${ }^{5}$ Office of Research Services, Health Sciences Division Loyola University, Chicago, IL, USA. \\ ${ }^{6}$ Department of Neurological Surgery Loyola University Medical Center, Maywood, IL, USA.
}

\begin{abstract}
Background: Intracranial meningiomas are rare in individuals under age 30 years. The purpose of this study was to analyze the demographics and clinical features of intracranial meningiomas in individuals under age 30 years.

Methods: A retrospective analysis of clinical, radiographic, and pathology data of patients under age 30 years who presented with an intracranial meningioma was performed.

Results: Thirty five patients met the criteria. Mean age was 25 years, 11 were male and 24 female. Five patients had previous radiation exposure. The presenting symptom was headache in 16 patients $(45.7 \%)$ and seizure in $9(25.7 \%)$. Cranial base tumors comprised $74 \%$; $26 \%$ were supratentorial. Simpson grade 1 or 2 resection was achieved in 16 patients (48.5\%); grade 3 or 4 resection was achieved in 17 patients (51.5\%). Tumor pathologic grade was WHO grade I in 27 (77.1\%), grade II in 6 (17.1\%) and grade III in 2 patients (5.7\%). Postoperative radiation therapy for tumor progression was administered in 13 patients. Radiographic follow-up was available in 26 patients at an average of 6.1 years after surgery; of these, 14 had no recurrence or progression of residual tumor while 12 had recurrence or progression. Recurrence was more common in patients with WHO grade II and III tumors and radiation-induced meningiomas. Recurrent tumors tended to have a higher WHO grade.

Conclusion: In this group of intracranial meningiomas in individuals $<30$ years, ionizing radiation was a risk factor and tumors were more common in females. A higher percentage of WHO grade II and III tumors at presentation and recurrence was noted. Recurrent tumors were more common in patients with higher WHO grade and in radiation-induced meningiomas.
\end{abstract}

Keywords: Meningioma, young adults, risk factors, radiation induced meningioma

\section{Introduction}

Meningiomas are relatively common extra-axial primary neoplasms that arise from arachnoid cap cells in the outer layer of the leptomeninges of the cranial and spinal compartments [1-4]. They are found in any area of the central nervous system (CNS) but are most common over the cerebral convexities or at the cranial base [4]. Meningiomas comprise approximately $33 \%$ of all primary brain tumors and the overall incidence in the general population is $2.3 / 100,000$ people [1-4]. The incidence of intracranial meningiomas increases with each decade of life and peaks in the 60-69 year age group among men (6.0/100000 people) and in the 70-79 year age group among women (9.5/100000 people) $[1-4,9]$. Meningiomas are rare in children and young adults; they represent $1-3 \%$ of all intracranial tumors in individuals up to age 20 years and $13.5 \%$ of intracranial tumors in the 20-34 age group [3-10]; both significantly lower than the incidence in patients over the age of $40[4,8,10]$. Sex differences are also evident among the age groups; among patients under the age of 20 years, they are more common in males while there is a female predominance in patients over the age of 20 years [4-10]. Meningiomas are categorized by the World Health Organization (WHO) into three grades that reflect increasing histological anaplasia and portend increasingly aggressive tumor behavior with greater risk of recurrence $[6,16,17]$. Other grading systems exist, including the Mayo system based on similarly objective histological criteria but the WHO system is most accepted $[16,17]$. A higher percentage of meningiomas in patients under the age of 20 years are histologically atypical or anaplastic, and display an aggressive pattern of growth and recurrence [4-6,11-13]. Multiplicity of meningiomas and intraventricular and infratentorial meningiomas are also more common in the younger age groups [4-7].

Meningiomas may occur sporadically or as part of a familial syndrome such as neurofibromatosis 2 (NF2), meningioangiomatosis (MA), or Gorlin's syndrome $[1,6,9]$. Genetic studies suggest meningiomas are clonal outgrowths from a single mutated cell and are frequently associated with chromosomal abnormalities which increase in frequency and complexity with increasing histological grade [1]. Deletion or inactivation of the NF2 gene on chromosome 22 is frequently seen in sporadic 
Prabhu et al. Neuroscience Discovery 2014,

meningiomas, although $1 p, 6 q, 14 q$, and $18 q$ deletions have also been reported [1,5-9]. Older patients tend to have sporadic tumors while patients under the age of 20 years tend to have meningiomas associated with one of these three syndromes $[1,6,9]$. Among exogenous factors, cranial ionizing radiation is the only exposure that confers an increased risk of intracranial meningioma formation $[\mathbf{1 , 4 , 6 , 1 4 - 1 6 ]}$. Individuals are exposed to cranial ionizing radiation in various forms; it may be administered during the course of diagnostic studies, or as part of a therapeutic prophylactic or treatment protocol, or accidental exposure from inadvertent or accidental environmental sources may occur $[4,6,8]$.

Previous studies have evaluated the demographics and clinical features of meningiomas in individuals under the age of 20 years $[5-7,9-13,18]$. This captures most meningiomas that occur as part of a familial syndrome or the rare sporadic meningioma in young individuals. However, given the long latency of post-radiation meningiomas, these tumors may not occur until the third decade of life. In addition, there are no studies that look at the occurrence of cranial base meningiomas in children and young adults. Our practice has a strong representation of cranial base tumors. The purpose of our study was to evaluate the demographics, risk factors, clinical presentation, radiological findings, histological findings, biological behavior, recurrence rates, and long-term outcome in patients who underwent initial surgical resection of a meningioma in the first three decades of life (<age 30 years) over the past 30 years at our institution.

\section{Methods}

Approval from the Institutional Review Board at Loyola University Medical Center/Stritch School of Medicine was obtained. A retrospective review of all cases of pathologically confirmed meningioma within the intracranial compartment in individuals under the age of 30 years at initial diagnosis treated at our institution over the past 30 years was performed. Patients were identified by clinical record review, ICD coding data, or from the neuropathology database. Each chart was reviewed for patient demographics, presenting symptoms and signs, tumor location and size, imaging findings, extent of surgical resection, histopathological findings, radiographic follow-up, tumor recurrence, and clinical outcome. The presence of genetic risk factors and exposure to cranial radiation was noted. Extent of tumor resection was determined by a review of the surgeon's intraoperative impression and postoperative imaging studies when available and graded as per the Simpson grading system. Tumor histopathology and WHO grading was recorded along with the Ki- 67 labeling index and progesterone receptor status, when available. Recurrence of tumor was defined as reappearance of tumor on imaging studies following Simpson Grade 1 or Grade 2 resection. Regrowth or progression of tumor was defined as any increase in size of known residual tumor on follow-up radiographic imaging. The need for repeat surgical intervention or use of radiation therapy following surgery was recorded. Length of follow-up was recorded along with Eastern cooperative oncology group (ECOG) performance score based on available clinical information at last evaluation.

Standard descriptive statistics are reported (Mean+ standard deviation for numerical variables and frequency count and percentage for categorical variables). Kaplan-Meier method was used for analysis of time to recurrence or progression and Cox proportional hazards model was used to examine the association between recurrence or progression and WHO grade while controlling for age and sex. Ordinal logistic regression was used to assess the effect of WHO grade and extent of resection on ECOG score at last follow-up while controlling for age and sex. A prospectively determined $p$ value equal to or less than 0.05 was used to imply a statistically significant difference. All statistical analysis was carried out using the SAS software package version 9.2 (SAS Institute Inc., Cary, NC).

\section{Results}

We identified 35 patients under the age of 30 years who were diagnosed with an intracranial meningioma at our institution over the past 30 years (Table 1). Mean age of the patients was 25 years (range 5-30 years) at the time of their initial surgery. Eleven were male (31.4\%) and 24 were female (68.5\%) and they underwent a total of 49 procedures. None of the patients had a diagnosis of neurofibromatosis or any other tumor syndrome. Five patients had previous exposure to ionizing radiation: two had childhood (at ages 5 and 6 years respectively) therapeutic prophylactic radiation for acute lymphocytic leukemia (ALL), one received craniospinal axis radiation at age 3 years for a posterior fossa medulloblastoma, one underwent radiation for the same tumor five years before presentation at our institution, and one patient had accidental exposure to environmental radiation. The latency period between radiation exposure and meningioma development in the two patients who received prophylactic cranial radiation for ALL was 24 and 25 years respectively and for the patient who received cranial radiation for medulloblastoma, it was 25 years. The latency period for the patient exposed to accidental environmental radiation was 20 years.

The most common presenting symptom was headache in 16 patients $(45.7 \%)$ followed by seizure in $9(25.7 \%)$, vision changes in $7(20 \%)$, weakness in $3(8.5 \%)$, and cranial nerve palsy in $2(5.7 \%)$. Tumors were located in the posterior cranial fossa in $10(28.5 \%)$, anterior cranial fossa in 9 (25.7\%), at the sphenoid ridge in $7(20 \%)$, and convexity or parafalcine location in 4 each (11.4\% each). One tumor was located within the ventricle (2.9\%). The average size of the tumor was 3.6 $\mathrm{cm}$ (Standard deviation: 1.74). Multiple meningiomas were noted in four patients (11.4\%); two of these patients has previous radiation exposure. Time from diagnosis to surgery averaged 1.5 years. Six patients had had previous resections at outside institutions and one had previous radiation therapy to the same tumor without tissue diagnosis. In these seven 
Prabhu et al. Neuroscience Discovery 2014,

Table 1. Demographic and Clinical data for the 35 patients who presented with intracranial meningiomas at $<30$ years of age.

\begin{tabular}{|c|c|c|c|c|c|c|}
\hline Age group & $<30$ years & -- & -- & -- & -- & -- \\
\hline Length of study & 30 years & -- & -- & -- & -- & -- \\
\hline Number of patients & 35 & -- & -- & -- & -- & -- \\
\hline Sex ratio & Male 12 : Female 23 & $\begin{array}{l}\text { Male } 34.2 \% \text { Female } \\
65.8 \%\end{array}$ & -- & -- & -- & -- \\
\hline $\begin{array}{l}\text { Presenting symptoms } \\
\text { and signs }\end{array}$ & Headache $16(45.7 \%)$ & Seizure $9(25.7 \%)$ & $\begin{array}{l}\text { Vision changes } 7 \\
(20 \%)\end{array}$ & $\begin{array}{l}\text { Weakness } 3 \\
(8.5 \%)\end{array}$ & $\begin{array}{l}\text { Cranial nerve } \\
\text { palsy } 2(5.7 \%)\end{array}$ & \\
\hline Location of tumors & PCF $10(28.5 \%)$ & ACF $9(25.7 \%)$ & $\begin{array}{l}\text { Sphenoid wing } 7 \\
(20 \%)\end{array}$ & $\begin{array}{l}\text { Convexity } 4 \\
(11.4 \%)\end{array}$ & $\begin{array}{l}\text { Parafalcine } 4 \\
(11.4 \%)\end{array}$ & $\begin{array}{l}\text { Intraventricu- } \\
\text { lar } 1(2.9 \%)\end{array}$ \\
\hline $\begin{array}{l}\text { Simpson Grade of } \\
\text { Resection ( } 29 \text { patients) }\end{array}$ & Grade 1: $8(27 \%)$ & Grade 2: $6(21 \%)$ & Grade 3: 3 (10\%) & Grade 4: $12(42 \%)$ & Grade 5: 0 & -- \\
\hline WHO Grade of Tumor & Grade I: 36 (73.4\%) & Grade II: 8 (16.3\%) & $\begin{array}{l}\text { Grade III: } 5 \\
(10.2 \%)\end{array}$ & -- & -- & -- \\
\hline $\begin{array}{l}\text { Radiographic followup } \\
\text { (25 patients) }\end{array}$ & No recurrence: $8(32 \%)$ & $\begin{array}{l}\text { Stable residual: } 10 \\
(40 \%)\end{array}$ & $\begin{array}{l}\text { Progression: } 7 \\
(28 \%)\end{array}$ & -- & -- & -- \\
\hline Average follow-up & 6.5 years & -- & -- & -- & -- & -- \\
\hline $\begin{array}{l}\text { ECOG at last follow-up } \\
\text { (23 patients) }\end{array}$ & Grade 0: 7 (30\%) & Grade 1: $12(52 \%)$ & Grade 2: $3(13 \%)$ & Grade 3: $1(5 \%)$ & -- & -- \\
\hline
\end{tabular}

PCF: Posterior cranial fossa; ACF: Anterior cranial fossa; WHO: World Health Organization

patients, the indication for surgery was progression of tumor on radiographic imaging studies (Table 1).

Accurate estimation of resection by the Simpson grading system was possible in 33 of the 35 patients. Grades 1 and 2 were considered together; similarly, grades 3 and 4 were grouped together. Simpson grade 1 or 2 resection was achieved in 16 patients (48.5\%) and Simpson grade 3 or 4 resection was achieved in 17 patients (51.5\%). No patient had a Simpson grade 5 (biopsy only) resection. All the tumors had histopathological features consistent with a diagnosis of meningioma. Documentation of brain invasion was available in 26 patients; of these four patients had documentation that suggested brain invasion noted at the time of surgery. Tumor pathologic grade in the 35 initial surgical specimens were WHO grade I in 27 (77.1\%), grade II in $6(17.1 \%)$ and grade III in 2 patients (5.7\%). Ten patients had more than one surgical procedure due to tumor recurrence producing 14 additional surgical specimens. Thus, when considering the total pathology database of 49 surgical specimens, WHO grade I tumors were noted in $36(73.4 \%)$, WHO II in 8 (16.3\%), and WHO III in 5 (10.2\%). Information about progesterone receptor status was available in 15 patients. All these 15 specimens were progesterone receptor positive at the time of initial resection. In one patient, the recurrent tumor resection specimen converted to progesterone receptor negative at the second surgery. Monoclonal antibody MIB-1 Ki-67 labeling index information was available in 15 patients and ranged from 1.5-20\%. In 9 (60\%) patients, the Ki-67 labeling index was greater than $5 \%$. In 33 patients, information was available about postoperative adjuvant radiation therapy. Of these, 13 patients (37.1\%) had postoperative adjuvant radiation therapy; in 9 of these patients, the tumors were WHO grade I and in 4 patients, they were WHO grade II or III.

Clinical follow-up for all patients averaged 6.5 years. There were no deaths recorded in any patient with documented follow-up. Follow-up information permitted ECOG score estimation in 23 patients. ECOG 0 was noted in 7 patients (30\%), ECOG 1 noted in 12 (52\%), ECOG 2 in $3(13 \%)$, and ECOG 3 in 1 patient (5\%) (Table 2). Immediate or early postoperative complications after initial surgery included cranial nerve palsy in 8 patients (16.6\%), cerebrospinal fluid (CSF) leak in 5 patients $(10.4 \%)$, hemiparesis in 4 patients $(8.3 \%)$, wound infection in 2 patients (4\%), hydrocephalus, subdural hematoma, new postoperative seizures and brainstem infarct in 1 patient each (2\% each) (Table 3). Among patients with cranial nerve palsy, three of eight improved and among patients with weakness, two of four patients improved. Four of the five patients with a CSF leak required operative repair. 
Prabhu et al. Neuroscience Discovery 2014,

http://www.hoajonline.com/journals/pdf/2052-6946-2-1.pdf

Table 2. Eastern cooperative oncology group (ECOG) score [96].

\begin{tabular}{|c|c|c|}
\hline Grade & $\begin{array}{l}\text { Number of Paients } \\
\text { (Percentage) }\end{array}$ & ECOG Functional Status \\
\hline 0 & $7(30 \%)$ & $\begin{array}{l}\text { Fully active, able to carry on all pre-disease } \\
\text { performance without restriction }\end{array}$ \\
\hline 1 & $12(52 \%)$ & $\begin{array}{l}\text { Restricted in physically strenuous activity } \\
\text { but ambulatory and able to carry out work } \\
\text { of a light or sedentary nature, e.g., light } \\
\text { house work, office work }\end{array}$ \\
\hline 2 & $3(13 \%)$ & $\begin{array}{l}\text { Ambulatory and capable of all selfcare but } \\
\text { unable to carry out any work activities. Up } \\
\text { and about more than } 50 \% \text { of waking hours }\end{array}$ \\
\hline 3 & $1(5 \%)$ & $\begin{array}{l}\text { Capable of only limited selfcare, confined } \\
\text { to bed or chair more than } 50 \% \text { of waking } \\
\text { hours }\end{array}$ \\
\hline 4 & 0 & $\begin{array}{l}\text { Completely disabled. Cannot carry on any } \\
\text { selfcare. Totally confined to bed or chair }\end{array}$ \\
\hline 5 & 0 & Dead \\
\hline
\end{tabular}

ECOG: Eastern Cooperative Oncology Group

Table 3. Summary of Postoperative Complications.

\begin{tabular}{ll}
\hline Complication & Frequency \\
\hline Cranial nerve palsies & $8(16.6 \%)$ \\
Improved & 3 \\
CSF leak & $5(10.4 \%)$ \\
Requiring operative repair & 4 \\
Weakness & $4(8.3 \%)$ \\
Improved & 2 \\
Wound infection requiring antibiotics & $2(4 \%)$ \\
Hydrocephalus, shunted & $1(2 \%)$ \\
Subdural hematoma & $1(2 \%)$ \\
Ventilator-dependent stroke & $1(2 \%)$ \\
New seizures & $1(2 \%)$ \\
\hline
\end{tabular}

There were two other patients that needed a return to the operating room: one for delayed presentation of a chronic subdural hematoma, and one porencephalic cyst associated with hydrocephalus that eventually required shunting for persistent symptoms. One other patient had a CSF leak that resolved with a lumbar drain. The patient with a brain stem infarct required long term assistance including tracheostomy and gastrostomy, and one patient with multiple cranial nerve deficits required tarsorraphy. The two wound infections resolved local debridement and antibiotics.

Radiographic follow-up was available in 26 patients at an average of 6.1 years after surgery. Of these 26 patients, 5 had Simpson grade 1 or 2 removal and no recurrence, 9 had Simpson grade 3 or 4 removal and no recurrence. Six patients had Simpson grade 1 or 2 removal and had recurrent tumors and six had Simpson grade 3 or 4 removal and recurrent tumor.
Of the patients with no recurrence following surgery and with adequate radiographic and clinical follow-up, 12 were WHO grade I and one was a WHO grade II and one a WHO grade III tumor. The former of these two patients had follow-up for 3 years and the latter was lost to follow-up after just one year. On the other hand, the follow-up for the group of 12 patients with WHO grade I tumors and no recurrence averaged 6.5 years. Of the six patients who had Simpson grade 1 or 2 removal and had recurrent tumors, five were WHO grade I and one was WHO grade II. In this subgroup, follow-up for the WHO grade I tumors averaged 5.6 years, while the single patient with a WHO grade II tumor was found to have a recurrence just 3 months after a Simpson grade 1 or 2 resection.

In all, 12 patients had evidence of tumor recurrence or regrowth of residual tumor on follow-up imaging studies (Table 4). Follow-up in these patients averaged 5 years, the average age was 25 years, six were male and six female, two had previous cranial radiation therapy for ALL, and one was exposed to environmental radiation, seven had WHO grade I tumors and five had WHO grade II tumors, nine were cranial base tumors and three supratentorial tumors. The average size of the tumors was $4.2 \mathrm{~cm}$, two patients had evidence of brain invasion at the time of surgery and six had undergone a Simpson grade 1 or 2 resection. The Ki-67 labeling index was reported in seven of these patients and ranged from $5-20 \%$. Five required adjuvant radiation therapy.

The subset of five patients with radiation exposure prior to surgery in our series of 35 patients are listed (Tables $\mathbf{5 a}$ and $\mathbf{5 b}$ ). Of these, four tumors were categorized as radiation-induced meningiomas (RIM) and one patient received fractionated radiation prior to surgery to a skull base tumor that had radiographic features suggestive of a meningioma but no histological confirmation at that time; this patient was excluded from the group of RIM. The group of four patients with RIM had three males and one female. Two patients had received childhood radiation for ALL and one had received radiation for treatment of a medulloblastoma. One patient was exposed to accidental environmental radiation from a nuclear facility meltdown. The average age was 29.3 years and the tumors presented after an average latency period of 23.5 years. Three of these tumors were skull base tumors and one was supratentorial; the average size of the tumors was $4.08 \mathrm{~cm}$. Two patients had multiple meningiomas. Brain infiltration was reported in two patients at the time of surgery. Two were WHO grade II tumors and two were WHO grade I. The Ki67 labeling index ranged from 2-10\% (average 4.75\%). All the tumors were positive for progesterone receptors. All four patients had a Simpson grade 1 or 2 resection and despite that three of these tumors recurred. Follow up in this group of RIM averaged 5.5 years. At last follow-up, three patients were doing well with an ECOG score of 0 and one had an ECOG score of 2 (ambulatory and capable of self-care but unable to work).

One patient in this group of RIM was exposed to radiation 
Prabhu et al. Neuroscience Discovery 2014 ,

http://www.hoajonline.com/journals/pdf/2052-6946-2-1.pdf

doi: $10.7243 / 2052-6946-2-1$

Table 4. Summary of cases with tumor recurrence.

\begin{tabular}{|c|c|c|c|c|c|c|c|c|c|c|c|c|}
\hline $\begin{array}{l}\text { Age } \\
\text { (Years) }\end{array}$ & Sex & Risk factors & Location & $\begin{array}{l}\text { Size } \\
(\mathrm{cm})\end{array}$ & $\begin{array}{l}\text { Brain } \\
\text { infiltration }\end{array}$ & $\begin{array}{l}\text { WHO } \\
\text { Grade }\end{array}$ & $\begin{array}{l}\text { Ki67 } \\
\text { LI }\end{array}$ & PR & $\begin{array}{l}\text { Extent of } \\
\text { Resection }\end{array}$ & $\begin{array}{l}\text { Adjuvant } \\
\text { treatment }\end{array}$ & $\mathrm{F} / \mathrm{U}(\mathbf{y r})$ & $\begin{array}{l}\text { ECOG at last } \\
\text { F/U }\end{array}$ \\
\hline 5 & $\mathrm{~F}$ & None & ST & 6.5 & - & I & - & Unk & GTR & None & 1 & Unknown \\
\hline 30 & M & TR & $\mathrm{ACF}$ & 2.9 & Yes & II & 10 & + & STR & SRT & 5 & 2 \\
\hline 30 & $\mathrm{~F}$ & None & ST & 3.1 & No & II & 5 & + & GTR & SRT / SRS & 0.25 & 2 \\
\hline 27 & M & None & $\begin{array}{l}\text { ACF, } \\
\text { MCF, } \\
\text { PCF }\end{array}$ & 4 & - & II & - & Unk & STR & Unknown & Unknown & Unknown \\
\hline 20 & $\mathrm{~F}$ & None & $\begin{array}{l}\text { ACF, } \\
\text { MCF }\end{array}$ & - & - & II & 20 & + & STR & None & 4 & Unknown \\
\hline 29 & M & ER & $\mathrm{ACF}$ & 8 & Yes & I & 2 & + & GTR & SRT / SRS & 7 & 0 \\
\hline 27 & $\mathrm{~F}$ & None & $\begin{array}{l}\text { ACF, } \\
\text { MCF, } \\
\text { PCF }\end{array}$ & 1 & No & I & - & Unk & STR & SRT & 7 & 2 \\
\hline 24 & $\mathrm{M}$ & $\begin{array}{l}\text { Previous } \\
\text { radiation }\end{array}$ & $\begin{array}{l}\text { ACF, } \\
\text { MCF }\end{array}$ & 5 & No & II & 10 & + & STR & SRT & 6 & 1 \\
\hline 17 & $\mathrm{~F}$ & None & $\mathrm{ACF}$ & 4 & No & I & 7 & + & GTR & None & 8 & 1 \\
\hline 30 & M & $\mathrm{TR}$ & ST & 2.9 & No & I & 5 & + & GTR & None & 6 & 0 \\
\hline 30 & $\mathrm{~F}$ & None & $\mathrm{ACF}$ & - & No & I & - & Unk & GTR & None & 6 & 0 \\
\hline 30 & M & None & ACF & - & Unk & I & Unk & Unk & STR & None & - & Unknown \\
\hline
\end{tabular}

(M:Male, F:Female, ST:Supratentorial, SB:Skull base, Unk:Unknown, WHO:World Health Organization, PR:Progesterone receptor, SRT:Stereotactic radiotherapy, SRS:Stereotactic radiosurgery, F/U:Followup, ECOG:Eastern cooperative oncology group)

Table 5a. Summary of Patients with Cranial Radiation Exposure.

\begin{tabular}{lllllllll}
\hline Patient & $\begin{array}{l}\text { Age at Presentation } \\
\text { (Years) }\end{array}$ & Sex & Radiation exposure & $\begin{array}{l}\text { Latency period } \\
\text { (Years) }\end{array}$ & Location & Size $(\mathbf{c m})$ & Number & $\begin{array}{l}\text { Brain } \\
\text { infiltration }\end{array}$ \\
\hline 1 & 30 & M & Treatment of ALL & 24 & ACF & 2.9 & M & Yes \\
2 & 29 & M & Environmental & 20 & ACF & 8 & S & Yes \\
3 & 28 & F & Medulloblastoma & 25 & PCF & 2.5 & S & No \\
4 & 30 & M & Treatment of ALL & 25 & ST & 2.9 & M & No \\
\hline
\end{tabular}

Table5b. Summary of Patients with Cranial Radiation Exposure.

\begin{tabular}{lllllllllll}
\hline Patient & WHO Grade & Ki67 LI & PR & $\begin{array}{l}\text { Simpson } \\
\text { Grade }\end{array}$ & $\begin{array}{l}\text { Postoperative } \\
\text { complications }\end{array}$ & $\begin{array}{l}\text { Adjuvant } \\
\text { treatment }\end{array}$ & Recurrence & F/U (yr) & $\begin{array}{l}\text { Progression at last } \\
\text { FU }\end{array}$ & $\begin{array}{l}\text { ECOG at } \\
\text { last FU }\end{array}$ \\
\hline 1 & II & 10 & + & 2 & Yes & SRT & Yes & 5 & Yes & 2 \\
2 & I & 2 & + & 1 & No & SRT / SRS & Yes & 7 & Yes & 0 \\
3 & II & 2 & + & 2 & No & None & No & 4 & No & 0 \\
4 & I & 5 & + & 1 & No & None & Yes & 6 & Yes & 0 \\
\hline
\end{tabular}

from the Chernobyl disaster at age 9 years. He presented with a large anterior cranial fossa lesion at age 29 years (Figure $1 \mathrm{~A}$ ) and underwent surgery. We were able to get a Simpson grade 1 resection that included all the involved bone and dura and then reconstructed the dura and calvarial defects with synthetic materials (Figure 1B). He recovered nicely after surgery. The initial pathology report suggested that this was a WHO grade I meningioma. However, given his history of radiation exposure, a second pathology review was performed and the final pathology was an atypical meningioma, WHO grade II, negative for progesterone receptors, with the Ki-67 labelling index elevated to $11 \%$ in some areas of the tumor, and deletions of chromosomes $1 p$ and 22q on fluoroscence in-situ hybridization (FISH). During the postoperative healing phase, he was noted to have a recurrence of tumor at six months from surgery (Figure 1C). He received fractionated 


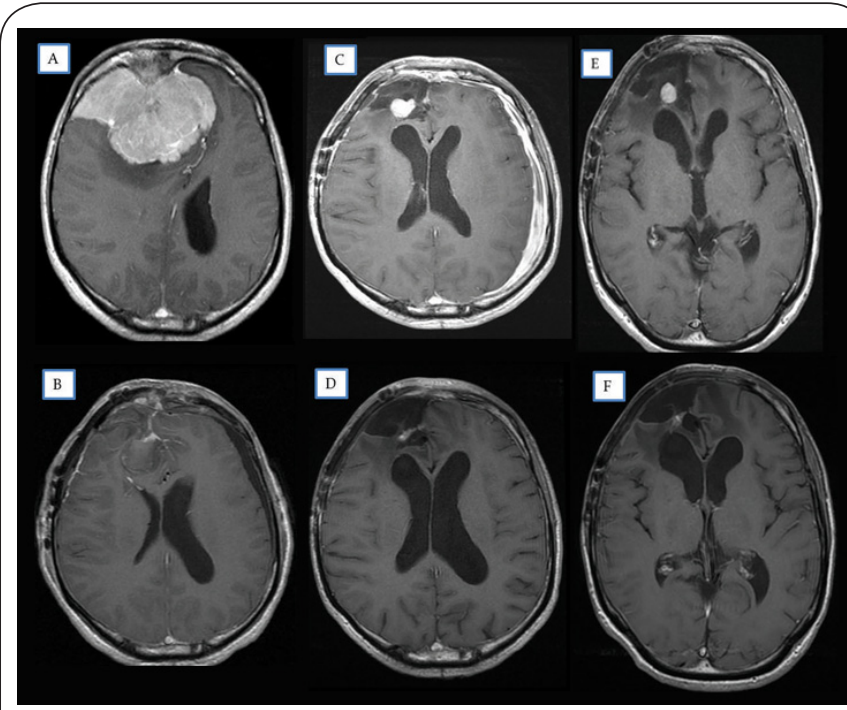

Figure 1. Initial presentation with large anterior cranial fossa lesion (A); Post-operative scan shows good resection (B); Recurrence of tumor at six months from surgery $(\mathbf{C})$ that was treated with fractionated radiation therapy along with rest of tumor bed with regression of the recurrent tumor (D); Three years from surgery, small, asymptomatic recurrence without mass effect (E); treated with stereotactic radiosurgery with good response approximately three years after radiosurgery (F).

radiotherapy to the entire tumor bed with a boost to the focal region of recurrent tumor with regression of this recurrent tumor (Figure 1D). At three years from surgery, he was noted to have a small, asymptomatic recurrence without mass effect (Figure 1E). This was treated with stereotactic radiosurgery with good response and no further recurrence noted on imaging approximately six years from his initial surgery (Figure 1F).

Analysis of time to recurrence or progression for the group of 24 patients with adequate radiographic follow-up was assessed using the Kaplan-Meier method. Difference between groups of WHO grade was compared by the two-sided logrank test. There was a significant difference in terms of time to recurrence or progression based on WHO grade $(p=0.0009)$ (Figure 2). There were a total of 18 patients with WHO grade 1 and 6 of them had recurrence/progression. There are 6 patients with WHO grade 2-3 and 4 of them had recurrence/ progression. Median time to recurrence or progression for patients with WHO grade I was 8 years, and that for patients with WHO grade II or III was 5 years (95\% Cl:0.25-6) (Figure 2). Multivariate Cox proportional hazards model was used to examine the association between recurrence or progression and WHO grade. Statistical adjustments were made for age and sex and hazard ratios with $95 \%$ confidence interval were reported. A strong prognostic effect of WHO grade $(p=0.0094)$ on recurrence or progression was noted. The hazard rate for tumor recurrence or progression of WHO grade II or III was 12.88 times ( $95 \% \mathrm{Cl}: 1.87-88.76$ ) that of WHO grade I (Figure 3).

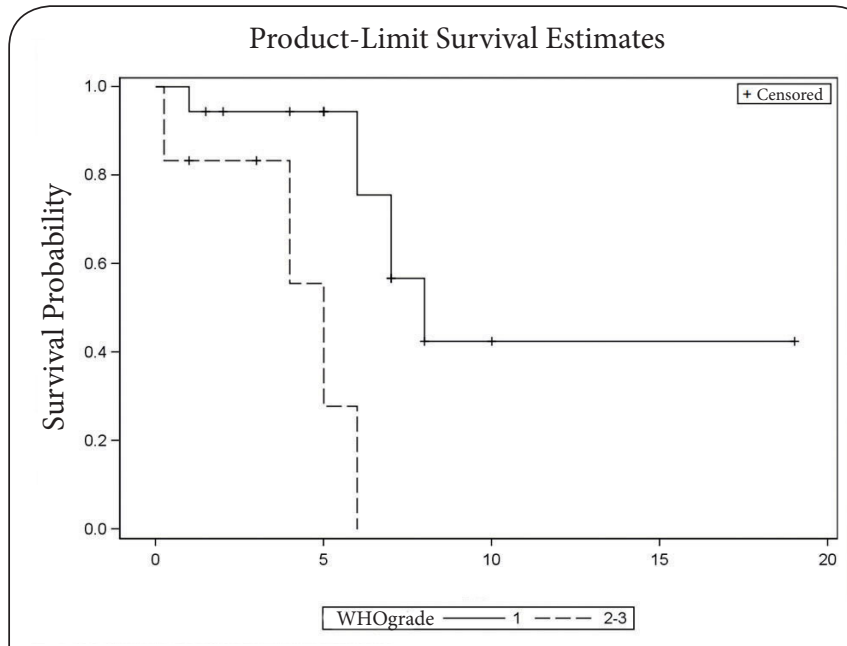

Figure 2. Kaplan-Meier analysis of time to recurrence or progression. Difference between groups of WHO grade was compared by the two-sided log-rank test. A significant difference by WHO grade was noted $(\mathrm{p}=0.0009)$.

Ordinal logistic regression was used to assess the association between ECOG score at last follow-up and categorical predictors, namely WHO grade and extent of resection. Statistical adjustments were made for age and sex. The WHO grade was once again a significant predictor of outcome $(p=0.03)$. A WHO grade II or III was 13.54 times ( $95 \% \mathrm{Cl}: 1.28$ 143.15) more likely than a WHO grade I to receive a higher score (Figure 4). Among 17 patients with WHO grade I, 16 (94\%)had an ECOG score of 0 or 1 at last follow-up, while among 6 patients with WHO grade II or III tumors, $3(50 \%)$ had an ECOG score of 0 or 1 at last follow-up. Extent of resection was not a significant predictor of outcome as assessed by the ECOG score $(p=0.20)$.

\section{Discussion}

Meningiomas in patients under the age of twenty are more frequent in males, and may be associated with genetic syndromes such as NF2 [5-7,9,19-32]. By contrast, among older patients, meningiomas are more common in females and less commonly associated with genetic syndromes. There is also a higher frequency of WHO grade II and WHO grade III tumors in the $<20$ year age group than seen in older age groups and they are more frequently multiple. $[5,6,23,26,30,31,33]$ lonizing radiation is a risk factor for both pediatric and adult patients because of the long latency period involved in the development of post-radiation brain tumors; other possible etiological factors such as cranial trauma or viruses have not been conclusively shown to have a role in the pathogenesis of meningiomas $[5,6,19,23,25,26,30,31,33]$. Most of the studies in the literature focus on the clinical and histological characteristics of meningiomas in patients $<20$ years of age (Table 6). This study extends that window by one decade and 


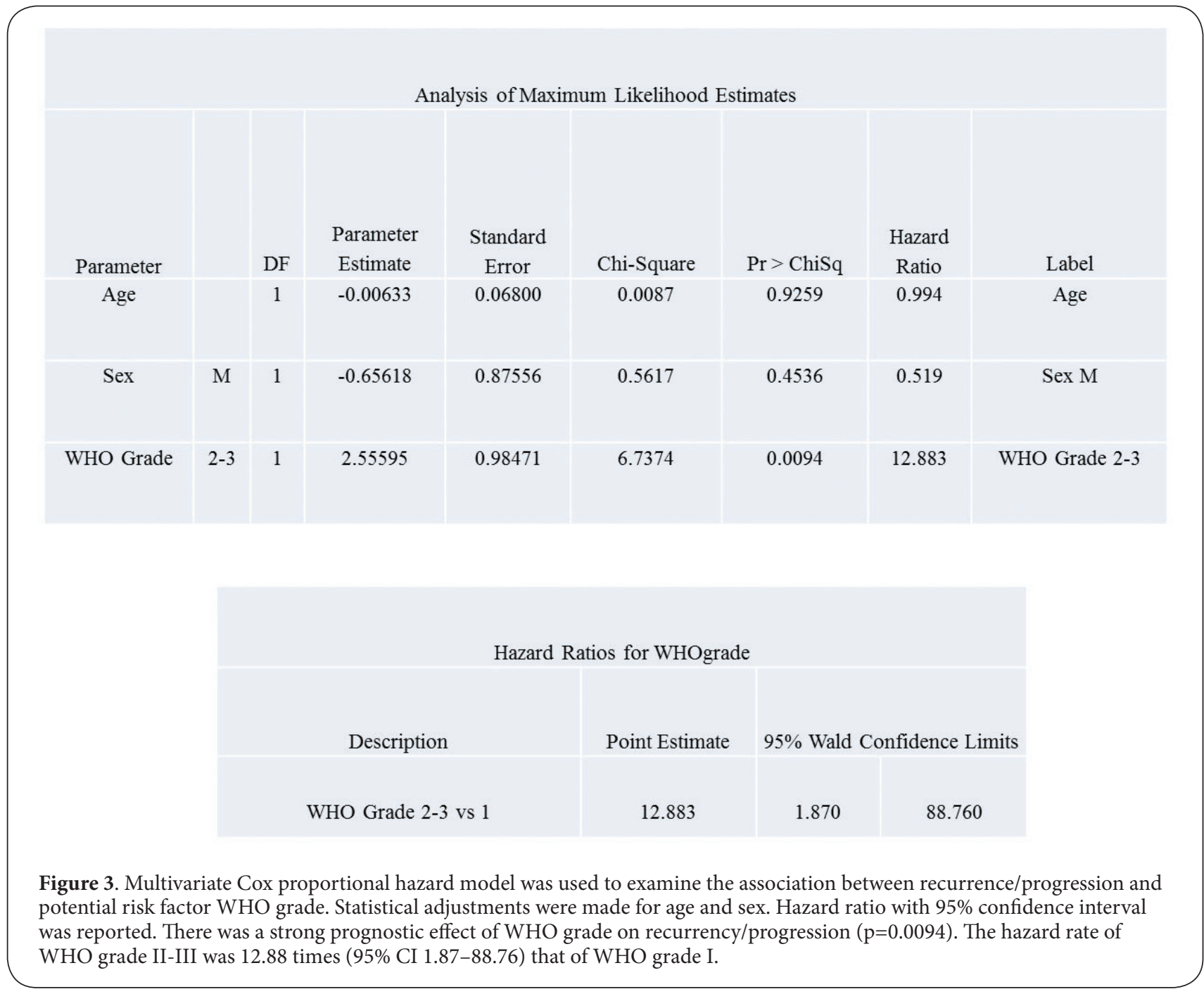

permits an analysis of a slightly different patient population.

\section{Genetic predisposition to intracranial meningioma} Meningiomas occur sporadically or as part of a familial syndrome such as NF2. This association is more pronounced in individuals $<20$ years of age. $[5-7,23,26,30,31,33]$. Other genetic syndromes that predispose to intracranial meningioma formation include MA, Gorlin's syndrome, and Down's Syndrome [6]. Meningioangiomatosis (MA) is a rare condition in which proliferation of arachnoidal tissue, fibroblasts and microvasculature is seen [34]. Meningiomas seen with MA tend to be WHO grade 1 lesions and slightly more common in males. Gorlin's syndrome or multiple basal cell carcinoma syndrome, is an autosomal dominant condition characterized by defects in the PTCH gene on chromosome $9[6,9]$. Defects in multiple body systems are seen along with an increased risk of intracranial meningioma development [6,34].

The association of intracranial meningiomas with NF2 is most commonly observed. With NF2, loss of heterozygosity of the NF2 gene on Chromosome 22q12.2, a tumor suppressor gene that encodes the protein merlin that links membrane receptors to the cytoskeleton, is frequently seen. Depletion of merlin constitutively activates mTORC 1 signaling, turning on cell cycling and promoting cell survival [35]. In NF2 patients, after vestibular schwanomma, meningioma is the second most common neoplasm and is seen in $53 \%$ of patients [34]. Patients with the Wishart variant of NF2 may be at even greater risk of developing a meningioma and do so at an earlier age [6]. Meningiomas seen in association with NF2 have a propensity to arise from the optic nerve sheath and within the spinal canal and are more frequently multiple $[9,24]$. Loss of NF2 gene expression is ubiquitous in NF2 patients with meningiomas, while this is seen in $40-60 \%$ of all sporadic meningiomas. It is possible that this genetic change may play a crucial role in meningioma formation, even in the absence of the NF2 syndrome $[9,22,24,36-38]$. None of the patients in this study had any predisposing genetic syndrome or genetic factors. This was in contrast to what was reported by other authors 


\section{Analysis of Maximum Likelihood Estimates}

\begin{tabular}{|c|c|c|c|c|c|c|}
\hline Parameter & & DF & Estimate & $\begin{array}{c}\text { Standard } \\
\text { Error }\end{array}$ & $\begin{array}{c}\text { Wald } \\
\text { Chi-Square }\end{array}$ & $\operatorname{Pr}>$ ChiSq \\
\hline Intercept & 4 & 1 & -2.4947 & 2.5363 & 0.9675 & 0.3253 \\
\hline Intercept & 2 & 1 & -0.6502 & 2.3904 & 0.0740 & 0.7856 \\
\hline Intercept & 1 & 1 & 2.6251 & 2.5095 & 1.0943 & 0.2955 \\
\hline Age & & 1 & -0.1103 & 0.0879 & 1.5766 & 0.2093 \\
\hline Sex & M & 1 & -0.1045 & 0.9303 & 0.0126 & 0.9105 \\
\hline WHO Grade & $2-3$ & 1 & 2.6053 & 1.2033 & 4.6876 & 0.0304 \\
\hline Extent of Resection & STR & 1 & 1.2193 & 0.9524 & 1.6393 & 0.2004 \\
\hline
\end{tabular}

\begin{tabular}{|c|c|c|c|c|}
\hline \multicolumn{5}{|c|}{ Odds Ratio Estimates } \\
\hline & Effect & Point Estimate & \multicolumn{2}{|c|}{$\begin{array}{c}95 \% \text { Wald } \\
\text { Confidence Limits }\end{array}$} \\
\hline & Age & 0.896 & 0.754 & 1.064 \\
\hline Sex & $\mathrm{M}$ vs $\mathrm{F}$ & 0.901 & 0.145 & 5.578 \\
\hline WHO Grade & $2-3$ vs 1 & 13.536 & 1.280 & 143.146 \\
\hline Extent of Resection & STR vs GTR & 3.385 & 0.523 & 21.888 \\
\hline
\end{tabular}

Figure 4. Ordinal logistical regression was used to assess the association between ECOG at last follow-up and categorical predictors WHO grade and extent of resection. Statistical adjustments for sex and age were made. Score test was used to assess the proportional odds assumption. WHO grade was significant a significant predictor ( $\mathrm{p}=0.03$ ). A WHO grade II-III had 13.54 times (95\% CI 1.28 - 143.15) the odds of receiving a higher score than WHO grade I.

when studying patients with intracranial meningiomas under the age of 20 years [6]. The average age in those studies was between 10 and 15 years, $[5,6,18,23,26,30,31,33]$ while the average age in our patient cohort was 25 years. It is possible that this is a reflection of the referral pattern to our practice and the representation of a more adult population accounted for this difference.

\section{Ionizing radiation and intracranial meningioma}

High energy ionizing radiation has the capacity to cause direct cellular DNA damage or indirect free-radical mediated DNA damage [4,39-42]. This form of radiation is in the high frequency, short wavelength end of the electromagnetic spectrum. Exposure less than $10 \mathrm{~Gy}$ is considered low grade while exposure above $10 \mathrm{~Gy}$ is considered high grade [42-47]. While cranial ionizing radiation can cause local effects such as alopecia, scalp atrophy, or microcephaly, it is also a recognized risk factor for the development of secondary intracranial tumors, in particular meningiomas $[1,9,14,15,27$ 29,41-47]. lonizing radiation may be administered as part of a therapeutic treatment plan, or a patient may be exposed to it during diagnostic studies such as computed tomography (CT) scans or x-ray angiographic studies $[1,4]$. Angiography, in particular, may result in high exposure doses for both the patient and the practitioner if performed without adequate lead shielding. Even dental x-rays may confer an increased risk particularly when administered to children under the age of 10 years, and may be particularly associated with the occurrence of meningiomas on the tentorium or below it $[\mathbf{1 , 4 , 8 , 4 4 ]}$. Radiation therapy, administered as part of a treatment plan such as for patients with medulloblastomas or pituitary adenomas, may increase the risk of meningioma formation 
Prabhu et al. Neuroscience Discovery 2014,

Table 6. Literature review of intracranial meningiomas in children and young adults.

\begin{tabular}{|c|c|c|c|c|c|c|c|c|c|c|c|c|c|}
\hline Authors & $\begin{array}{l}\text { Age } \\
\text { group }\end{array}$ & $\begin{array}{l}\text { Time } \\
\text { period } \\
\text { (years) }\end{array}$ & $\begin{array}{l}\text { \# of } \\
\text { Patients }\end{array}$ & \multicolumn{2}{|c|}{ Seizure } & $\begin{array}{l}\text { Motor } \\
\text { deficit }\end{array}$ & $\mathrm{CN}$ palsy & $\begin{array}{l}\text { Raised } \\
\text { ICP }\end{array}$ & Headache & $\begin{array}{l}\text { Loss of } \\
\text { vision }\end{array}$ & Ataxia & Syndrome & $\begin{array}{l}\text { Previous } \\
\text { Radiation }\end{array}$ \\
\hline $\begin{array}{l}\text { Germano } \\
1994\end{array}$ & $0-20 y$ & 42 & 23 & \multicolumn{2}{|l|}{$25 \%$} & $33 \%$ & NS & $25 \%$ & NS & NS & NS & NF (3) & 2 \\
\hline $\begin{array}{l}\text { Erdingler, } \\
1998\end{array}$ & $0-15 y$ & 26 & 29 & \multicolumn{2}{|l|}{ NS } & $21 \%$ & $14 \%$ & $41 \%$ & NS & NS & NS & NF1 (7), NF2(5) & NS \\
\hline Rushing, 2005 & $0-20 y$ & 22 & 87 & \multicolumn{2}{|c|}{$33 \%$} & $10 \%$ & NS & NS & $13 \%$ & NS & $10 \%$ & $\begin{array}{l}\text { NF2(9), Gorlin(2), } \\
\text { Down (1) }\end{array}$ & 7 \\
\hline Gao, 2009 & $0-18 y$ & 15 & 54 & \multicolumn{2}{|l|}{$35 \%$} & $22 \%$ & $26 \%$ & $30 \%$ & $37 \%$ & $22 \%$ & $6 \%$ & NF2 (5) & 0 \\
\hline Menon, 2009 & $0-20 y$ & 27 & 38 & \multicolumn{2}{|l|}{$76 \%$} & $39 \%$ & $13 \%$ & $71 \%$ & NS & $34 \%$ & NS & NF1 (8), NF2 (3) & 1 \\
\hline Thuijs, 2012 & $0-18 y$ & 35 & 72 & \multicolumn{2}{|c|}{$28 \%$} & NS & NS & $36 \%$ & NS & NS & NS & NF2(13) & 4 \\
\hline Santos, 2012 & $0-18 y$ & 16 & 15 & \multicolumn{2}{|c|}{$20 \%$} & NS & NS & $20 \%$ & $40 \%$ & NS & NS & NF2 (5) & 6 \\
\hline $\begin{array}{l}\text { Ravindranath, } \\
2013\end{array}$ & $0-18 y$ & 24 & 31 & \multicolumn{2}{|c|}{$36 \%$} & $36 \%$ & $9 \%$ & $32 \%$ & NS & $6 \%$ & NS & NF1 (2), NF2(2) & NS \\
\hline LUMC, 2013 & $0-30 y$ & 30 & 35 & \multicolumn{2}{|c|}{$26 \%$} & $9 \%$ & $6 \%$ & NS & $46 \%$ & $20 \%$ & NS & 0 & 5 \\
\hline Authors & \multicolumn{2}{|c|}{ Supratentorial } & \multicolumn{2}{|c|}{ Infratentorial } & Multiple & GTR & WHO I & \multicolumn{2}{|c|}{ WHO II } & WHO III & $\mathrm{F} / \mathrm{U}$ & Recurrence & $\begin{array}{l}\text { Good } \\
\text { Outcome }\end{array}$ \\
\hline Germano 1994 & $70 \%$ & & $13 \%$ & & NS & $60 \%$ & $71 \%$ & $29 \%$ & & - & $12.9 y$ & 0 & $100 \%$ \\
\hline Erdingler, 1998 & $81 \%$ & & $19 \%$ & & $7 \%$ & $86 \%$ & $94 \%$ & $3 \%$ & & $3 \%$ & $6.5 y$ & NS & NS \\
\hline Rushing, 2005 & $76 \%$ & & $16 \%$ & & NS & $62 \%$ & $71 \%$ & $24 \%$ & & $5 \%$ & $6.5 y$ & $19 \%$ & NS \\
\hline Gao, 2009 & $70 \%$ & & $28 \%$ & & NS & $72 \%$ & $82 \%$ & $11 \%$ & & $7 \%$ & $5 y$ & $30 \%$ & $82 \%$ \\
\hline Menon, 2009 & $49 \%$ & & $32 \%$ & & $7 \%$ & $49 \%$ & $73 \%$ & $22 \%$ & & $5 \%$ & $5 y$ & $18 \%$ & $84 \%$ \\
\hline Thuijs, 2012 & $58 \%$ & & $18 \%$ & & $6 \%$ & $55 \%$ & $74 \%$ & $18 \%$ & & $8 \%$ & $5 y$ & $26 \%$ & $\begin{array}{l}5 y \text { PFS } 56 \% \text {, } \\
\text { OS } 84 \%\end{array}$ \\
\hline Santos, 2012 & $50 \%$ & & $17 \%$ & & $20 \%$ & $80 \%$ & $73 \%$ & $27 \%$ & & - & $5 y$ & $33 \%$ & $80 \%$ \\
\hline $\begin{array}{l}\text { Ravindranath, } \\
2013\end{array}$ & $51 \%$ & & $49 \%$ & & $6 \%$ & $83 \%$ & $64 \%$ & $36 \%$ & & - & $4 y$ & $64 \%$ & $81 \%$ \\
\hline LUMC, 2013 & $71 \%$ & & $29 \%$ & & $9 \%$ & $48 \%$ & $73 \%$ & $16 \%$ & & $10 \%$ & $6.5 y$ & $12 \%$ & NS \\
\hline
\end{tabular}

ICP: Intracranial pressure, GTR: Gross total resection

$[4,6]$. Therapeutic cranial radiation may be administered prophylactically in some instances such as in the treatment of ALL patients at high-risk for CNS relapse or small-cell lung cancer patients [41-43,45-51]. At times, it is considered in the management of non-small-cell lung cancer patients as well [42]. The life expectancy of lung cancer patients, both small-cell and non-small-cell, may be shorter than the latency period for the development of an intracranial tumor and hence, this patient population is rarely considered in this context. On the other hand, children with ALL who receive prophylactic cranial radiation at a young age, frequently in the first decade of life, are uniquely susceptible to developing intracranial tumors such as meningiomas as they have excellent long-term survival with current chemotherapy and radiation therapy treatments [27-29]. In addition, arachnoidal tissues in children may be uniquely susceptible to the oncogenic effects of ionizing radiation [25]. Age at exposure also has an impact on the latency period of tumor development and the type of tumor that develops. Exposure below age 20 years may predispose to meningioma development while exposure above the age of 20 years may predispose more towards sarcoma development [50].

Acute lymphoblastic leukemia (ALL) is one of the most common cancers in children and comprises $23 \%$ of all mali-gnancies

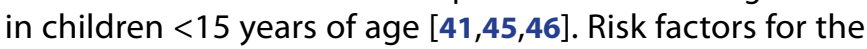
development of ALL include prenatal exposure to x-rays or post-natal exposure to high-dose radiation. Among genetic factors, NF also confers an increased risk of ALL development. Patients are treated with induction chemotherapy that continues into a consolidation and maintenance phases and $>90 \%$ achieve remission with $>80 \%$ expected to be long term

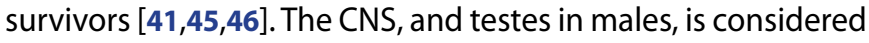
a sanctuary site that is relatively impermeable to the effects of systemic chemotherapy. Involvement of the CNS is seen in $3 \%$ of patients at initial presentation and without prophylactic treatment, most high risk patients will develop CNS disease 
Prabhu et al. Neuroscience Discovery 2014,

during the course of their illness [14,15,27-29,41-43,45-47]. Patients who receive prophylactic cranial irradiation for ALL have a lifetime relative risk of developing a RIM or other intracranial tumor due to the long survival effected by the treatment of the primary malignancy [15]. Among 60 patients with ALL treated prophylactically with cranial radiation, $22 \%$ developed intracranial meningiomas after an average of 25 years following the radiation exposure [25]. The incidence of intracranial meningiomas further increased when the patients were followed for longer periods of time [25]. However, with increasing awareness of radiation induced malignancies in this specific patient population, the dose has been reduced and the option is carefully exercised in select cases only. The success of intrathecal chemotherapy to supplement systemic chemotherapy protocols has spurred ongoing trials seeking to eliminate cranial radiation altogether from ALL protocols. Prophylactic cranial radiation is hence administered to patients in a high-risk category [15,27,41-43,45-47]. Ionizing radiation exposure may also occur accidentally from environmental sources or following natural disasters that cause breakdown of facilities that release damaging radiation into the air, ground, or water. Atomic bomb survivors and those exposed to large doses of radiation from accidental causes such as the nuclear plant meltdown at Chernobyl are at risk of development of cranial or non-CNS malignancies $[39,44,52]$.

Tinea capitis is a relatively common fungal infection of the scalp caused by the Trichophyton species $[42,47,53,54]$. Prior to 1960 , Tinea capitis was treated with scalp radiation as per the Adamson-Kleinbock technique $[42,47]$. Estimates of exposure were $5-8 \mathrm{~Gy}$ to the scalp, $1.5 \mathrm{~Gy}$ to the brain, and $0.7 \mathrm{~Gy}$ to the cranial base and a 10 -fold relative risk of developing an intracranial meningioma has been reported in this population $[1,53]$. Sadetzki et al., reported 253 cases of RIM from among a cohort of 11,000 children treated as per this protocol for tinea capitis [54]. When compared to a similar group of non-RIM meningiomas, these tended to occur in younger patients, were frequently calvarial and multiple and had a higher tendency to recur after resection [54]. The average latency period was 36 years [40]. Modan et al., estimated the relative risk of RIM following scalp radiation to be 9 times greater with exposure of 1-2 Gy and 18 times greater with exposure above $2.6 \mathrm{~Gy}$ [40]. The use of cranial radiation for tinea capitis ceased after 1960 with the introduction of griseofulvin [53]. It may hence be possible that this epidemic has peaked and the cohort of patients with RIM and other intracranial malignancies as a result of tinea capitis radiation will remain static.

Radiation induced neoplasms occur in the field of radiation following a variable latency period that depends on the total dose and age of the individual and may have unique histological and genetic characteristics $[4,6,54]$. Radiation induced meningiomas (RIM) tend to arise in younger individuals, are more frequent in males, have more aggressive histological features, higher WHO grades, are more frequently multiple, and a greater tendency to recur
[4,6,27,40-51]. NF2 mutations or chromosome 22 abnormalities are uncommon while chromosome $1 p, 6 q$, and $7 p$ deletions are more commonly seen $[17,42,54,55]$. In addition, when compared to sporadic meningiomas, RIM are more likely to be located over the convexities [4]. The incidence of RIM also may increase with increased length of follow-up $[27,29]$. The cumulative actuarial risk of developing a RIM is $0.53 \%$ at 10 years, $1.2 \%$ at 20 years and $8.8 \%$ at 25 years [29]. The latency period for the development of a RIM is between 20-35 years and varies depending on age at exposure and the total dose; higher doses and younger ages portend shorter latency periods $[4,25,42,47]$. In rare instances, it may be even shorter; Choudhary et al., reported one case of RIM that occurred after a latency period of just 14 months [50]. Others estimate latency periods of 10.8 years for pediatric patients and 18.7 years for adult patients $[29,49]$.

Five of the 35 patients in this study had a history of previous radiation exposure. Two of the five had received prophylactic cranial radiation as part of a treatment protocol for ALL and one patient received craniospinal axis radiation for treatment of a posterior fossa medulloblastoma. One patient had received previous radiation therapy to a cranial base meningioma that was already present. Of the two patients who received prophylactic cranial radiation for ALL, one had an anterior cranial base tumor that was WHO grade II and recurred multiple times. One patient in this study had exposure to a large dose of radiation from a nuclear power plant accident and environmental contamination as a child, but the exact dose he received was not discernible. The average latency period for the patients who had therapeutic or environmental exposure to radiation in this series was 23.5 years. None of the patients in our study had a history of tinea capitis or received cranial radiation for this indication.

\section{Demographics of patients and location of tumors}

Pediatric meningiomas are characterized by a slight male predominance as compared to meningiomas in adults wherein a female predominance is noted $[\mathbf{1 , 4 - 6 , 1 8 ]}$. The increase in female to male ratio gets more pronounced with increasing age $[\mathbf{1 , 4 - 6 , 1 8}]$. In this series where the average age of the patients was 25 years and none of the patients had any syndromic abnormalities, females outnumbered males almost 2:1. It is possible that these variables portend a trend towards female predominance; that is, intracranial meningiomas in young adults without syndromic associations may be more common in women. The average age among the 12 patients with recurrent tumors was 25 years and in this subgroup as well females outnumbered males. The average age among patients with radiation induced tumors was 29.3 years; slightly older than the rest of the cohort which may be because they presented after an average latency period of 23.5 years following radiation exposure.

The cerebral convexity is the most frequent location for adults with intracranial meningiomas. By contrast, some 
authors report intraventricular and infratentorial meningiomas are more common in children $[5,7,9]$. Other series reach varying conclusions; Germano et al., reported 23 cases of intracranial meningiomas in children under age 20 years and noted that $2 / 3$ rds were supratentorial in location, and $13 \%$ were intraventricular [18]. In the series of 87 patients reported by Rushing et al., $64 \%$ of the tumors were supratentorial, $16 \%$ infratentorial, and $12 \%$ intraventricular [6]. In the series reported by Amirjamshidi et al., $75 \%$ of the meningiomas were supratentorial [9]. Meningiomas with a lack of dural attachment are more frequent in children [5]. In our series, 26 of the 35 patients $(74.28 \%)$ of the tumors were cranial base neoplasms and only one was located within the ventricle. This may be a reflection of the referral pattern to our institution which has a high representation of cranial base cases.

\section{Surgery, histopathology and recurrence of tumor}

Large meningiomas that cause significant mass effect on adjacent parenchyma are best surgically removed along with their dural base and involved bone; this is categorized as a Simpson grade 1 resection [56-58]. In the event that the dura cannot be removed, it is coagulated constituting a Simpson grade 2 removal [56-58]. These are probably the best options for a patient with a meningioma, if they can be safely executed [56-58]. Large lesions that invade or are intimately associated with critical structures such as the cavernous sinus may be debulked and the residual component monitored with radiographic imaging studies or treated with radiosurgery or radiotherapy in the event of radiographic progression $[59,60]$. Radiosurgery is an option for meningiomas that are small $(<3 \mathrm{~cm})$ but show radiographic progression, or if they are located in a surgically inaccessible location or location where the risk of surgical intervention is significant [61-67]. It is also an option for residual meningiomas that show radiographic progression but cannot be removed surgically $[59,60,63]$. A meningioma that is small and not causing significant mass effect on the adjacent parenchyma in an asymptomatic patient may be observed with serial imaging studies and clinical follow-up $[68,69]$.

Accurate estimation of resection by the Simpson grading system was possible in 33 of the 35 patients; this was based on a review of the operative notes and postoperative imaging when available. Simpson grade 1 or 2 resection was achieved in only 16 patients (48.5\%). This number is lower than the resection rates achieved with supratentorial convexity meningiomas but consistent with other major published series of cranial base neoplasms; $>60 \%$ of tumors in this series were cranial base meningiomas $[26,70]$. Similarly, morbidity following surgery may be a function of tumor location and relationship to critical neurovascular structures and treatment modality. Superficial convexity lesions have a significantly lower morbidity associated with surgery than cranial base lesions that are in proximity to critical neurovascular structures. The most common complication in this series was cranial nerve palsy that was observed following surgery in $8(16.6 \%)$ patients and that was permanent in 5 . Cerebrospinal fluid leakage was noted in $5(10.4 \%)$ patients and required operative repair in 4. Other complications included motor weakness in $4(8.3 \%)$ patients that was permanent in 2 . Wound infection occurred in $2(4 \%)$ patients while one patient developed hydrocephalus that required a permanent CSF diversion.

Recurrence after surgery is related to the extent of resection and WHO grade of the tumor $[60,67,71-76]$. Recurrence rates of RIM are higher even after Simpson grade 1 or 2 resections [55]. In Al-Mefty's series of 16 patients with RIM, all the tumors recurred after first resection. A second recurrence was noted in $62 \%$ and a third recurrence in 17\% [55]. The final pathology results in our series reflected a higher proportion of WHO grade II (16.3\%) and WHO grade III (10.2\%) tumors than seen in older adults but was similar to reported rates in series of intracranial meningiomas in individuals $<20$ years age (Table 6). Adjuvant radiotherapy was administered to residual tumors or the tumor bed in $10(28 \%)$ patients and all these patients had WHO grade II or III tumors. Radiation exposure and WHO grade had an impact on recurrence in this series. Among the 12 patients who had evidence of tumor recurrence or regrowth of residual tumor on follow-up imaging studies (Table 4), two had previous cranial radiation therapy for ALL, and one was exposed to environmental radiation, seven had WHO grade I tumors and five had WHO grade II tumors. In addition, recurrence was more common with cranial base tumors as we were not able to achieve as complete a resection with these as with supratentorial convexity meningiomas.

In contrast to what is reported in the literature, we observed a higher rate of recurrence with RIM. The patient treated with craniospinal axis radiation for medulloblastoma had a WHO grade II meningioma that recurred once. The patient with environmental exposure had a WHO grade II tumor in the anterior cranial fossa that recurred twice. The patient who received neoadjuvant radiation five years before his eventual surgery for significant radiographic progression prompting the first surgery that revealed a WHO grade II meningioma and required two additional surgeries for significant recurrent tumor following Simpson grade 4 resections. This was a lesion located at the petrous apex with involvement of the cavernous sinus and basilar perforators. Tumor pathologic grade also had a trend towards higher WHO grades on recurrence. The distribution of WHO grades in the 35 initial surgical specimens was WHO grade I in $77.1 \%$, grade II in $17.1 \%$ and grade III in $5.7 \%$. When considering the additional 14 surgical specimens, the distribution was WHO grade I in $73.4 \%$, WHO II in $16.3 \%$, and WHO III in $10.2 \%$.

Estrogen and progesterone receptor status of meningiomas are purported to have prognostic significance and may suggest the increased frequency of these tumors in women and the increase in growth during pregnancy and following menopause. [77-86] Progesterone receptor positivity is more common in grade 1 tumors and is a good prognostic sign. 
Prabhu et al. Neuroscience Discovery 2014,

http://www.hoajonline.com/journals/pdf/2052-6946-2-1.pdf

doi: 10.7243/2052-6946-2-1

$[\mathbf{7 8 , 8 0 , 8 1 ]}$ Increased estrogen receptor expression may correlate with chromosome 14 and 22 alterations, molecular markers identified in meningothelial cell neoplastic transformation. [78] At times, meningiomas may regress with cessation of progesterone agonist medications [82]. However, there is no evidence that exogenous hormone use increases the risk of developing meningiomas $[83,84]$. Progesterone receptor status may be more prevalent with increasing age at diagnosis of a meningioma [86]. This data was only available in 13 patients in our study and 12 of them had tumors that stained positive for progesterone receptors. Given the limited numbers, progesterone receptor status information was inadequate to make firm conclusions of its impact on tumor recurrence. The Ki-67 labeling index is an estimate of the proliferating cells within a tumor. It thus reflects cells in all phases of the cell cycle except the G0 phase. The MIB-1 monoclonal antibody is used to stain the Ki-67 antigen and the labeling index is a subjective histopathological estimate that estimates the growth potential of a tumor [87-92]. Similarly, with meningiomas, higher Ki-67 labeling indices are concordant with higher tumor grades and predictive of tumor regrowth or recurrence [87]. With meningiomas, higher Ki-67 labeling indices are observed males, recurrent tumors, and those located in a skull base location [69]. Age is not considered to be a factor in the Ki-67 labeling indices of meningiomas, and when increased Ki-67 labeling indices are noted in childhood meningiomas, it is postulated that it does not predict recurrence or prognosis $[6 \mathbf{6 9 8}$. Of the 15 patients in whom this information was available, the $\mathrm{Ki}-67$ labeling index was $>5 \%$ in $9(60 \%)$ patients. Once again, although there was a trend towards higher $\mathrm{Ki}-67$ labeling indices, there were insufficient numbers of patients to make firm conclusions of the impact this had on recurrence of tumor or outcome.

The selection of radiation therapy for a radiation-induced neoplasm may seem counter-intuitive but has been reported previously by other authors with varying degrees of success [42, 93-95]. In general, these options are considered for recurrent progressive lesions in surgically inaccessible areas [42,75,93-95]. In our patient with a RIM following environmental exposure, we employed the option of fractionated radiotherapy at the first recurrence because it was our intent to treat the entire tumor bed as this was a WHO grade II neoplasm. The subsequent recurrence was small and focal and stereotactic radiosurgery was effective and considered less morbid than surgery (removal of synthetic cranioplasty and dural reconstructive implants). The patient responded well to the treatments without additional morbidity. Both fractionated radiotherapy and stereotactic radiosurgery have been reported as treatments for RIM. Single fraction radiosurgery may be more effective than fractionated treatments but each case has to be carefully assessed to determine which modality is more suitable [94,95].

The purpose of this study is to shed light on the demographics and clinical characteristics of meningiomas in patients below 30 years of age. It does have certain limitations, particularly because the data sampling extended back 30 years and some patients lacked adequate histological grading, immunohistochemical analysis, or proliferative index estimation, or were lost to clinical and radiographic followup. However, despite these constraints it does provide some useful information. In particular, with the average age of the patients being 25 years, there was a female predominance as opposed to male predominance observed in meningiomas in individuals less than 20 years of age. The distribution of WHO grades paralleled that observed in patients under 20 years with a higher representation of WHO grades II and III than seen in older adults. The Ki-67 labeling index tended to be higher but this information was not available in sufficient numbers of patients to draw firm conclusions. The WHO grade had a significant impact on outcome. Previous radiation exposure and WHO grade II and III tumors had higher recurrence rates.

\section{Conclusion}

When analyzing meningiomas in the first three decades of life in an adult practice with a strong representation of cranial base cases, we observed an average age at presentation of 25 years with a female predominance. A greater proportion of cases were WHO grades II and III compared to what is seen in older adults. Previous radiation exposure and higher WHO grade increased the risk of recurrence and tumors tended to be of a higher WHO grade at recurrence.

\section{List of abbreviations}

CNS: Central nervous system

WHO: World Health Organization

NF2: Neurofibromatosis 2

MA: Meningioangiomatosis

ECOG: Eastern cooperative oncology group

ALL: Acute lymphocytic leukemia

CSF: Cerebrospinal fluid

RIM: Radiation-induced meningiomas

FISH: Fluoroscence in-situ hybridization

CT: Computed tomography

MRI: Magnetic resonance imaging

Competing interests

The authors declare that they have no competing interests.

Authors' contributions

\begin{tabular}{|l|c|c|c|c|c|c|}
\hline Authors' contributions & VCP & ECP & EM & KB & RG & DEA \\
\hline Research concept and design & $\checkmark$ & $\checkmark$ & -- & -- & -- & -- \\
\hline $\begin{array}{l}\text { Collection and/or assembly of } \\
\text { data }\end{array}$ & $\checkmark$ & $\checkmark$ & -- & -- & -- & -- \\
\hline Data analysis and interpretation & $\checkmark$ & -- & -- & -- & $\checkmark$ & -- \\
\hline Writing the article & $\checkmark$ & -- & $\checkmark$ & $\checkmark$ & -- & - \\
\hline Critical revision of the article & $\checkmark$ & -- & $\checkmark$ & $\checkmark$ & -- & $\checkmark$ \\
\hline Final approval of article & $\checkmark$ & -- & $\checkmark$ & $\checkmark$ & -- & $\checkmark$ \\
\hline Statistical analysis & -- & -- & -- & -- & $\checkmark$ & -- \\
\hline
\end{tabular}

Acknowledgement

The authors would like to thank Dr. Thomas C. Origitano, Dr. O 
Prabhu et al. Neuroscience Discovery 2014,

Howard Reichman, and Dr. John F. Shea for care provided to patients included in this study.

\section{Publication history}

EIC: Tadanori Tomita, Northwestern University Feinberg School of Medicine, USA.

Received: 25-Jul-2013 Revised: 05-Dec-2013

Accepted: 19-Dec-2013 Published: 08-Jan-2014

\section{References}

1. Wiemels J, Wrensch $M$ and Claus EB. Epidemiology and etiology of meningioma. J Neurooncol. 2010; 99:307-14. | Article | PubMed Abstract | PubMed Full Text

2. Rohringer $M$, Sutherland GR, Louw DF and Sima AA. Incidence and clinicopathological features of meningioma. J Neurosurg. 1989; 71:66572. | Article | PubMed

3. Hinsdale IL. Central Brain Tumor Registry of the United States (CBTRUS). Statistical report 2000-2004. | Website

4. Bondy $M$ and Ligon BL. Epidemiology and etiology of intracranial meningiomas: a review. J Neurooncol. 1996; 29:197-205. | Article | PubMed

5. Erdincler $P$, Lena $G$, Sarioglu AC, Kuday $C$ and Choux M. Intracranial meningiomas in children: review of 29 cases. Surg Neurol. 1998; 49:13640. | Article | PubMed

6. Rushing EJ, Olsen C, Mena H, Rueda ME, Lee YS, Keating RF, Packer RJ and Santi M. Central nervous system meningiomas in the first two decades of life: a clinicopathological analysis of 87 patients. J Neurosurg. 2005; 103:489-95. | Article | PubMed

7. Turgut $M, O z c a n ~ O E$ and Bertan V. Meningiomas in childhood and adolescence: a report of 13 cases and review of the literature. $\mathrm{Br} J$ Neurosurg. 1997; 11:501-7. | PubMed

8. Claus EB, Bondy ML, Schildkraut JM, Wiemels JL, Wrensch M and Black PM. Epidemiology of intracranial meningioma. Neurosurgery. 2005; 57:1088-95. | Article | PubMed

9. Amirjamshidi A, Mehrazin M and Abbassioun K. Meningiomas of the central nervous system occurring below the age of 17: report of 24 cases not associated with neurofibromatosis and review of literature. Childs Nerv Syst. 2000; 16:406-16. | Article I PubMed

10. Drake JM, Hendrick EB, Becker LE, Chuang SH, Hoffman HJ and Humphreys RP. Intracranial meningiomas in children. Pediatr Neurosci. 1985; 12:134-9. | Article | PubMed

11. Caroli E, Russillo $M$ and Ferrante L. Intracranial meningiomas in children: report of $\mathbf{2 7}$ new cases and critical analysis of $\mathbf{4 4 0}$ cases reported in the literature. J Child Neurol. 2006; 21:31-6. | Article | PubMed

12. Demirtas E, Ersahin Y, Yilmaz F, Mutluer S and Veral A. Intracranial meningeal tumours in childhood: a clinicopathologic study including MIB-1 immunohistochemistry. Pathol Res Pract. 2000; 196:151-8. | Article I PubMed

13. Tufan K, Dogulu F, Kurt G, Emmez H, Ceviker N and Baykaner MK. Intracranial meningiomas of childhood and adolescence. Pediatr Neurosurg. 2005; 41:1-7. I Article | PubMed

14. De Tommasi A, Occhiogrosso M, De Tommasi C, Cimmino A, Sanguedolce $F$ and Vailati G. Radiation-induced intracranial meningiomas: review of six operated cases. Neurosurg Rev. 2005; 28:104-14. | Article | PubMed

15. Foreman NK, Laitt RD, Chambers EJ, Duncan AW and Cummins BH. Intracranial large vessel vasculopathy and anaplastic meningioma 19 years after cranial irradiation for acute lymphoblastic leukaemia. Med Pediatr Oncol. 1995; 24:265-8. | Article | PubMed

16. Riemenschneider MJ, Perry A and Reifenberger G. Histological classification and molecular genetics of meningiomas. Lancet Neurol. 2006; 5:1045-54. I Article I PubMed

17. Perry A, Stafford SL, Scheithauer BW, Suman VJ and Lohse CM. Meningioma grading: an analysis of histologic parameters. Am J Surg Pathol. 1997; 21:1455-65. | Article | PubMed
18. Germano IM, Edwards MS, Davis RL and Schiffer D. Intracranial meningiomas of the first two decades of life. J Neurosurg. 1994; 80:44753. | Article | PubMed

19. Annegers JF, Laws ER, Jr., Kurland LT and Grabow JD. Head trauma and subsequent brain tumors. Neurosurgery. 1979; 4:203-6. | Article | PubMed

20. Biegel JA, Parmiter AH, Sutton LN, Rorke LB and Emanuel BS. Abnormalities of chromosome 22 in pediatric meningiomas. Genes Chromosomes Cancer. 1994; 9:81-7. | PubMed

21. Perry A, Gutmann DH and Reifenberger G. Molecular pathogenesis of meningiomas. J Neurooncol. 2004; 70:183-202. | Article | PubMed

22. Wellenreuther R, Kraus JA, Lenartz D, Menon AG, Schramm J, Louis DN, Ramesh V, Gusella JF, Wiestler OD and von Deimling A. Analysis of the neurofibromatosis $\mathbf{2}$ gene reveals molecular variants of meningioma. Am J Pathol. 1995; 146:827-32. | PubMed Abstract | PubMed Full Text

23. Ravindranath K, Vasudevan MC, Pande A and Symss N. Management of pediatric intracranial meningiomas: an analysis of 31 cases and review of literature. Childs Nerv Syst. 2013; 29:573-82. | Article | PubMed

24. Hartmann C, Sieberns J, Gehlhaar C, Simon M, Paulus W and von Deimling A. NF2 mutations in secretory and other rare variants of meningiomas. Brain Pathol. 2006; 16:15-9. | Article | PubMed

25. Banerjee J, Paakko E, Harila M, Herva R, Tuominen J, Koivula A, Lanning $M$ and Harila-Saari A. Radiation-induced meningiomas: a shadow in the success story of childhood leukemia. Neuro Oncol. 2009; 11:543-9. | Article | PubMed Abstract | PubMed Full Text

26. Burkhardt JK, Neidert MC, Grotzer MA, Krayenbuhl N and Bozinov $O$. Surgical resection of pediatric skull base meningiomas. Childs Nerv Syst. 2013; 29:83-7. | Article | PubMed

27. Salvati M, Cervoni L and Artico M. High-dose radiation-induced meningiomas following acute lymphoblastic leukemia in children. Childs Nerv Syst. 1996; 12:266-9. | Article | PubMed

28. Stein ME, Drumea K, Guilbord JN, Ben-Itzhak O and Kuten A. Case report: late aggressive meningioma following prophylactic cranial irradiation for acute lymphoblastic leukaemia. Br J Radiol. 1995; 68:1123-5. | Article I PubMed

29. Strojan P, Popovic M and Jereb B. Secondary intracranial meningiomas after high-dose cranial irradiation: report of five cases and review of the literature. Int J Radiat Oncol Biol Phys. 2000; 48:65-73. | Article | PubMed

30. Thuijs NB, Uitdehaag BM, Van Ouwerkerk WJ, van der Valk P, Vandertop WP and Peerdeman SM. Pediatric meningiomas in The Netherlands 1974-2010: a descriptive epidemiological case study. Childs Nerv Syst. 2012; 28:1009-15. | Article | PubMed Abstract | PubMed Full Text

31. Santos MV, Furlanetti L, Valera ET, Brassesco MS, Tone LG and de Oliveira RS. Pediatric meningiomas: a single-center experience with 15 consecutive cases and review of the literature. Childs Nerv Syst. 2012; 28:1887-96. | Article | PubMed

32. Lanzafame S, Torrisi A, Barbagallo G, Emmanuele C, Alberio N and Albanese V. Correlation between histological grade, MIB-1, p53, and recurrence in 69 completely resected primary intracranial meningiomas with a 6 year mean follow-up. Pathol Res Pract. 2000; 196:483-8. | Article I PubMed

33. Menon G, Nair S, Sudhir J, Rao BR, Mathew A and Bahuleyan B. Childhood and adolescent meningiomas: a report of 38 cases and review of literature. Acta Neurochir (Wien). 2009; 151:239-44. | Article I PubMed

34. Kotecha RS, Pascoe EM, Rushing EJ, Rorke-Adams LB, Zwerdling T, Gao X, Li X, Greene S, Amirjamshidi A, Kim SK, Lima MA, Hung PC, Lakhdar F, Mehta N, Liu Y, Devi BI, Sudhir BJ, Lund-Johansen M, Gjerris F, Cole CH and Gottardo NG. Meningiomas in children and adolescents: a metaanalysis of individual patient data. Lancet Oncol. 2011; 12:1229-39. | Article I PubMed

35. Lopez-Lago MA, Okada T, Murillo MM, Socci N and Giancotti FG. Loss of the tumor suppressor gene NF2, encoding merlin, constitutively activates integrin-dependent mTORC1 signaling. Mol Cell Biol. 2009; 29:4235-49. | Article | PubMed Abstract | PubMed Full Text 
Prabhu et al. Neuroscience Discovery 2014,

36. Leuraud P, Dezamis E, Aguirre-Cruz L, Taillibert S, Lejeune J, Robin E, Mokhtari K, Boch AL, Cornu P, Delattre JY and Sanson M. Prognostic value of allelic losses and telomerase activity in meningiomas. $J$ Neurosurg. 2004; 100:303-9. I Article | PubMed

37. Kleihaus $P$ and Cavanee WK. Pathology and genetics of tumors of the nervous system. International Agency for Research on Cancer. IARC Press, Lyon, France, 2000. I Book

38. Perry A, Scheithauer BW, Stafford SL, Lohse CM and Wollan PC. "Malignancy" in meningiomas: a clinicopathologic study of 116 patients, with grading implications. Cancer. 1999; 85:2046-56. | Article PubMed

39. Preston DL, Ron E, Yonehara S, Kobuke T, Fujii H, Kishikawa M, Tokunaga $\mathrm{M}$, Tokuoka $\mathrm{S}$ and Mabuchi K. Tumors of the nervous system and pituitary gland associated with atomic bomb radiation exposure. J Nat/ Cancer Inst. 2002; 94:1555-63. | Article | PubMed

40. Modan B, Baidatz D and Mart H. Radiation-induced head and neck tumors. Lancet. 1974; 1:277-279.

41. Kawahara I, Masui K, Horie N, Matsuo T, Kitagawa N, Tsutsumi K, Nagata I, Morikawa $\mathrm{M}$ and Hayashi T. Radiation-induced meningioma following prophylactic radiotherapy for acute lymphoblastic leukemia in childhood. Pediatr Neurosurg. 2007; 43:36-41. | Article | PubMed

42. Umansky F, Shoshan Y, Rosenthal G, Fraifeld S and Spektor S. Radiationinduced meningioma. Neurosurg Focus. 2008; 24:E7. | Article | PubMed

43. Soffer D, Gomori JM, Siegal T and Shalit MN. Intracranial meningiomas after high-dose irradiation. Cancer. 1989; 63:1514-9. | Article | PubMed

44. Claus EB, Calvocoressi L, Bondy ML, Schildkraut JM, Wiemels JL and Wrensch M. Dental x-rays and risk of meningioma. Cancer. 2012; 118:4530-7. | Article | PubMed Abstract | PubMed Full Text

45. Hijiya N, Hudson MM, Lensing S, Zacher M, Onciu M, Behm FG, Razzouk BI, Ribeiro RC, Rubnitz JE, Sandlund JT, Rivera GK, Evans WE, Relling MV and Pui $\mathrm{CH}$. Cumulative incidence of secondary neoplasms as a first event after childhood acute lymphoblastic leukemia. JAMA. 2007; 297:1207-15. | Article | PubMed

46. Ron E, Modan B, Boice JD, Jr., Alfandary E, Stovall M, Chetrit A and Katz $L$. Tumors of the brain and nervous system after radiotherapy in childhood. N Engl J Med. 1988; 319:1033-9. | Article | PubMed

47. Harrison MJ, Wolfe DE, Lau TS, Mitnick RJ and Sachdev VP. Radiationinduced meningiomas: experience at the Mount Sinai Hospital and review of the literature. J Neurosurg. 1991; 75:564-74. | Article | PubMed

48. Mack EE and Wilson CB. Meningiomas induced by high-dose cranial irradiation. J Neurosurg. 1993; 79:28-31. | Article | PubMed

49. Ghim TT, Seo JJ, O'Brien M, Meacham L, Crocker I and Krawiecki N. Childhood intracranial meningiomas after high-dose irradiation. Cancer. 1993; 71:4091-5. | Article | PubMed

50. Choudhary A, Pradhan S, Huda MF, Mohanty S and Kumar M. Radiation induced meningioma with a short latent period following high dose cranial irradiation - case report and literature review. J Neurooncol. 2006; 77:73-7. | Article | PubMed

51. Sadetzki S, Flint-Richter P, Ben-Tal T and Nass D. Radiation-induced meningioma: a descriptive study of 253 cases. J Neurosurg. 2002; 97:1078-82. | Article | PubMed

52. Rahu M, Rahu K, Auvinen A, Tekkel M, Stengrevics A, Hakulinen T, Boice JD, Jr. and Inskip PD. Cancer risk among Chernobyl cleanup workers in Estonia and Latvia, 1986-1998. Int J Cancer. 2006; 119:162-8. | Article | PubMed

53. Gupta AK, Adam P, Dlova N, Lynde CW, Hofstader S, Morar N, Aboobaker $J$ and Summerbell RC. Therapeutic options for the treatment of tinea capitis caused by Trichophyton species: griseofulvin versus the new oral antifungal agents, terbinafine, itraconazole, and fluconazole. Pediatr Dermatol. 2001; 18:433-8. | Article | PubMed

54. Rajcan-Separovic E, Maguire J, Loukianova T, Nisha M and Kalousek D. Loss of $1 p$ and $7 p$ in radiation-induced meningiomas identified by comparative genomic hybridization. Cancer Genet Cytogenet. 2003; 144:6-11. | Article | PubMed

55. Al-Mefty O, Topsakal C, Pravdenkova S, Sawyer JR and Harrison MJ.
Radiation-induced meningiomas: clinical, pathological, cytokinetic, and cytogenetic characteristics. J Neurosurg. 2004; 100:1002-13. | Article | PubMed

56. Simpson $D$. The recurrence of intracranial meningiomas after surgical treatment. J Neurol Neurosurg Psychiatry. 1957; 20:22-39. | Article | PubMed Abstract | PubMed Full Text

57. Sughrue ME, Kane AJ, Shangari G, Rutkowski MJ, McDermott MW, Berger MS and Parsa AT. The relevance of Simpson Grade I and II resection in modern neurosurgical treatment of World Health Organization Grade I meningiomas. J Neurosurg. 2010; 113:1029-35. | Article | PubMed

58. Hasseleid BF, Meling TR, Ronning P, Scheie D and Helseth E. Surgery for convexity meningioma: Simpson Grade I resection as the goal: clinical article. J Neurosurg. 2012; 117:999-1006. | Article | PubMed

59. Abdel-Aziz KM, Froelich SC, Dagnew E, Jean W, Breneman JC, Zuccarello $M$, van Loveren HR and Tew JM, Jr. Large sphenoid wing meningiomas involving the cavernous sinus: conservative surgical strategies for better functional outcomes. Neurosurgery. 2004; 54:1375-83; discussion 13834. | Article | PubMed

60. El-Khatib M, El Majdoub F, Hoevels M, Kocher M, Muller RP, Steiger $\mathrm{HJ}$, Sturm $\mathrm{V}$ and Maarouf M. Stereotactic LINAC radiosurgery for incompletely resected or recurrent atypical and anaplastic meningiomas. Acta Neurochir (Wien). 2011; 153:1761-7. | Article | PubMed

61. Kondziolka D, Mathieu D, Lunsford LD, Martin JJ, Madhok R, Niranjan A and Flickinger JC. Radiosurgery as definitive management of intracranial meningiomas. Neurosurgery. 2008; 62:53-8. | Article | PubMed

62. Pollock BE, Stafford SL, Utter A, Giannini C and Schreiner SA. Stereotactic radiosurgery provides equivalent tumor control to Simpson Grade 1 resection for patients with small- to medium-size meningiomas. Int $J$ Radiat Oncol Biol Phys. 2003; 55:1000-5. | Article | PubMed

63. Goldsmith BJ, Wara WM, Wilson CB and Larson DA. Postoperative irradiation for subtotally resected meningiomas. A retrospective analysis of 140 patients treated from 1967 to 1990. J Neurosurg. 1994; 80:195-201. | Article | PubMed

64. Torres RC, Frighetto L, De Salles AA, Goss B, Medin P, Solberg T, Ford JM and Selch M. Radiosurgery and stereotactic radiotherapy for intracranial meningiomas. Neurosurg Focus. 2003; 14:e5. | Article | PubMed

65. Lo SS, Cho KH, Hall WA, Kossow RJ, Hernandez WL, McCollow KK, Gerbi BJ, Higgins PD, Lee CK and Dusenbery KE. Single dose versus fractionated stereotactic radiotherapy for meningiomas. Can J Neurol Sci. 2002; 29:240-8. | Article | PubMed

66. Linskey ME, Davis SA and Ratanatharathorn V. Relative roles of microsurgery and stereotactic radiosurgery for the treatment of patients with cranial meningiomas: a single-surgeon 4-year integrated experience with both modalities. J Neurosurg. 2005; 102 Suppl:59-70. | Article I PubMed

67. Milosevic MF, Frost PJ, Laperriere NJ, Wong CS and Simpson WJ. Radiotherapy for atypical or malignant intracranial meningioma. Int $J$ Radiat Obcol Biol Phys. 1996; 34:817-822.

68. Olivero WC, Lister JR and Elwood PW. The natural history and growth rate of asymptomatic meningiomas: a review of 60 patients. $J$ Neurosurg. 1995; 83:222-4. | Article | PubMed

69. Kasuya H, Kubo O, Tanaka M, Amano K, Kato K and Hori T. Clinical and radiographic features related to the growth potential of meningiomas. Neurosurg Rev. 2006; 29:293-296. I Article

70. Nanda A, Javalkar $V$ and Banerjee AD. Petroclival meningiomas: study on outcomes, complications and recurrence rates. J Neurosurg. 2011; 114:1268-77. | Article | PubMed

71. Mirimanoff RO, Dosoretz DE, Linggood RM, Ojemann RG and Martuza RL. Meningioma: analysis of recurrence and progression following neurosurgical resection. J Neurosurg. 1985; 62:18-24. | Article | PubMed

72. Adegbite $\mathrm{AB}, \mathrm{Khan} \mathrm{MI}$ and Paine $\mathrm{KW}$ et al. The recurrence of intracranial meningiomas after surgical treatment. J Neurosurg. 1983; 58:51-56.

73. Jaaskelainen J. Seemingly complete removal of histologically benign intracranial meningioma: late recurrence rate and factors predicting recurrence in 657 patients. A multivariate analysis. Surg Neurol. 1986; 
Prabhu et al. Neuroscience Discovery 2014,

26:461-9. | Article | PubMed

74. Jaaskelainen J, Haltia M and Servo A. Atypical and anaplastic meningiomas: radiosurgery, surgery and radiotherapy and outcome. Surg Neurol. 1986; 25:233-242.

75. Modha A and Gutin PH. Diagnosis and treatment of atypical and anaplastic meningiomas: a review. Neurosurgery. 2005; 57:538-50. I Article I PubMed

76. Ko KW, Nam DH, Kong DS, Lee JI, Park K and Kim JH. Relationship between malignant subtypes of meningioma and clinical outcome. J Clin Neurosci. 2007; 14:747-53. I Article I PubMed

77. Sarkar A and Chiocca EA. Prognostic indicators. J Neurosurg. 2006; 105:161-2. | Article I PubMed

78. Pravdenkova S, Al-Mefty O, Sawyer J and Husain M. Progesterone and estrogen receptors: opposing prognostic indicators in meningiomas. $J$ Neurosurg. 2006; 105:163-73. I Article I PubMed

79. Donnell MS, Meyer GA and Donegan WL. Estrogen-receptor protein in intracranial meningiomas. J Neurosurg. 1979; 50:499-502. | Article | PubMed

80. Hsu DW, Efird JT and Hedley-Whyte ET. Progesterone and estrogen receptors in meningiomas: prognostic considerations. J Neurosurg. 1997; 86:113-20. | Article | PubMed

81. Gabos S and Berkel J. Meta-analysis of progestin and estrogen receptors in human meningiomas. Neuroepidemiology. 1992; 11:255-60. | Article I PubMed

82. Vadivelu S, Sharer L and Schulder M. Regression of multiple intracranial meningiomas after cessation of long-term progesterone agonist therapy. J Neurosurg. 2010; 112:920-4. I Article I PubMed

83. Claus EB, Black PM, Bondy ML, Calvocoressi L, Schildkraut JM, Wiemels $\mathrm{JL}$ and Wrensch $\mathrm{M}$. Exogenous hormone use and meningioma risk: what do we tell our patients? Cancer. 2007; 110:471-6. I Article I PubMed

84. Custer B, Longstreth WT, Jr., Phillips LE, Koepsell TD and Van Belle G. Hormonal exposures and the risk of intracranial meningioma in women: a population-based case-control study. BMC Cancer. 2006; 6:152. | Article | PubMed Abstract | PubMed Full Text

85. Korhonen K, Salminen T, Raitanen J, Auvinen A, Isola J and Haapasalo $H$. Female predominance in meningiomas can not be explained by differences in progesterone, estrogen, or androgen receptor expression. J Neurooncol. 2006; 80:1-7. | Article | PubMed

86. Roser FG, Nakamura $M$ and Ritz $R$ et al. Proliferation and estrogen receptor status in benign meningiomas are not age dependent. Cancer. 2005; 104:598-601. | Article

87. Tyagi $A$, Chakrabarty $A$ and Franks A. MIB1 proliferation index in meningiomas: does it predict recurrence? A clinicopathological study. Br J Neurosurg. 2004; 18:357-61. | Article I PubMed

88. Roser F, Samii M, Ostertag H and Bellinzona M. The Ki-67 proliferation antigen in meningiomas. Experience in 600 cases. Acta Neurochir (Wien). 2004; 146:37-44. | Article I PubMed

89. Abramovich CM and Prayson RA. MIB-1 labeling indices in benign, aggressive, and malignant meningiomas: a study of 90 tumors. Hum Pathol. 1998; 29:1420-7. | Article | PubMed

90. Hsu DW, Efird JT and Hedley-Whyte ET. MIB-1 (Ki-67) index and transforming growth factor-alpha (TGF alpha) immunoreactivity are significant prognostic predictors for meningiomas. Neuropathol Appl Neurobiol. 1998; 24:441-52. | Article I PubMed

91. Cobb MA, Husain M, Andersen BJ and al-Mefty O. Significance of proliferating cell nuclear antigen in predicting recurrence of intracranial meningioma. J Neurosurg. 1996; 84:85-90. | Article | PubMed

92. Kallio M, Sankila R, Hakulinen T and Jaaskelainen J. Factors affecting operative and excess long-term mortality in $\mathbf{9 3 5}$ patients with intracranial meningioma. Neurosurgery. 1992; 31:2-12. | Article | PubMed

93. Mathiesen T. Radiation-induced meningiomas: the paradox of radiation treatment. Neurosurg Focus. 2008; 24:E6. I Article I PubMed

94. Kondziolka D, Kano H, Kanaan H, Madhok R, Mathieu D, Flickinger JC and Lunsford LD. Stereotactic radiosurgery for radiation-induced meningiomas. Neurosurgery. 2009; 64:463-9. I Article I PubMed

95. Kuhn EN, Chan MD, Tatter SB and Ellis TL. Gamma knife stereotactic radiosurgery for radiation-induced meningiomas. Stereotact Funct Neurosurg. 2012; 90:365-9. | Article I PubMed

96. Oken MM, Creech RH, Tormey DC, Horton J, Davis TE, McFadden ET and Carbone PP. Toxicity and response criteria of the Eastern Cooperative Oncology Group. Am J Clin Oncol. 1982; 5:649-55. | Article | PubMed

\section{Citation:}

Prabhu VC, Perry EC, Melian E, Barton K, Guo $\mathrm{R}$ and Anderson DE. Intracranial meningiomas in individuals under the age of 30; Analysis of risk factors, histopathology, and recurrence rate. Neurosci Discov. 2014; 2:1. http://dx.doi.org/10.7243/2052-6946-2-1 